Article

\title{
Segregated in the City, Separated in the School. The Reproduction of Social Inequality through the School System
}

\author{
Aina Gomà Garcia * and Joel Muñoz Aranda * \\ Research Group on Energy, Territory and Society, Department of Geography, Autonomous University of \\ Barcelona, 08193 Bellaterra (Cerdanyola del Vallès), Spain \\ * Correspondence: aina.goma@uab.cat (A.G.); joel.munoz@e-campus.uab.cat (J.M.)
}

Received: 20 October 2018; Accepted: 21 November 2018; Published: 27 November 2018

\begin{abstract}
This paper explores the relationship between urban segregation and the educational level of the population. In the first place, the impacts of segregation in educational careers are analysed. Secondly, the contribution explores the interrelationship between urban segregation and schooling in Barcelona. For this aim, different sources have been used: The map of urban segregation in Catalonia at the census tract level; data about the formal educational levels of the population, aged between 15 and 34 years, from the Catalan Youth Survey (Enquesta de Joventut de Catalunya); and schooling data in Barcelona's schools and neighbourhoods. The research shows how urban segregation effects the educational level and fosters social inequalities amongst neighbourhoods. It also points out how choosing school and enrolment strategies could act by increasing school segregation in Barcelona. Therefore, the role of segregation in the reproduction and perpetuation of inequalities in the living conditions of the population is exposed.
\end{abstract}

Keywords: urban segregation; school choice; educational level; social inequalities; neighbourhood effect

\section{Introduction}

Studies about social inequalities and differences in living conditions have often paid little attention to spatial issues. The available literature shows that, when territorial factors have been taken into account, they have been mainly focused on the classic categories of countryside and city or urban and rural. Conversely, differences inside the main urban areas, which require an approach at a highly detailed scale, have often been overlooked.

In the current stage of the urbanisation process-when the social, infrastructural, and territorial transformations of recent decades have brought about increasing territorial integration and an extension of the urban areas and urban conditions [1] — this detailed perspective takes on even greater importance. As is widely known, territorial integration has implied that the differences between the former urban and rural areas have declined and have lost explanatory power [2,3]. In contrast, spatial inequalities associated with the phenomena of spatial segregation have gained importance [4]. Spatial segregation is defined as the trend of social groups to split in the urban space according to their socio-economic profiles. This is then one of the most relevant and worrying aspects in the process of capitalist urbanisation and touches on the international debate about the significance of space in the (re)production of social inequality [3,5].

Residential segregation is the result of the differentiated capacity of social groups to choose their place of residence depending on the price of land and housing. As is clearly evident, for persons and families with the highest income levels the widest scope of choice is available. In the opposite sense, the most socially vulnerable groups are confined to those neighbourhoods in which housing prices 
are lowest, these often being the ones that accumulate the greatest urban planning deficits, the worst conditions in terms of habitability, reduced accessibility, and a downscaled service offer.

The existence of segregation has given rise to a significant debate and wide-ranging literature regarding its effects on living conditions and the opportunities offered to the population, something which has become known as the "neighbourhood effect" [6-9]. In this debate, the issue of reproduction of inequalities through the school system plays a significant role. The issues coming to the fore cannot, certainly, be belittled: Are the scholarly performances of schools in vulnerable neighbourhoods worse than those in other areas? Are equal opportunities affected by having been schooled in one of these schools? Do the relatively well-off families residing in vulnerable neighbourhoods tend to send their offspring to schools in other neighbourhoods? Does this set of factors contribute to the settling, increase, and perpetuation of social inequalities in the city?

To respond to these issues, the analysis of the relationship between urban segregation, on the one hand, and school segregation, on the other, is essential. The latter may be defined as the unequal distribution of students amongst schools located in the same region in accordance with a certain individual- or family-based characteristic [10]. It refers to a situation in which the schools in the same region enrol markedly different student profiles, depending on, firstly, the socio-economic status of their families. Many authors have studied the scope, causes, and impact of this phenomenon, largely from the seventies onwards, especially on the United States exploring racial segregation in schools [11]. Although there is no clear agreement on this matter, certain writers have signalled educational systems with quasi-market operative systems as a fundamental reason for school segregation. Increased possibility of choice tends to nurture dynamics such as the fleeing of the middle-class population from schools with greater concentrations of ethnic minorities in a similar way to the so-called "white flight" [10,12]. This phrase became common in the middle of the 20th century in the United States and refers to the migration of the white population away from heterogeneous urban areas to settle in socially homogenous ones. The social composition of schools tends to sharpen segregation creating a spiral that would lead the most vulnerable centres and students into decline [13-15]. Recent reports have suggested that school segregation is a genuine issue in Barcelona and Catalonia, as it is in all the major Spanish and European metropolitan areas $[10,16]$.

Our contribution tackles this general debate and aims to provide reflections based on the combination of a triple line of analysis: Knowledge of the dynamics of urban segregation; educational levels achieved by the population aged between 15 and 34; and enrolment strategies and scholar performance according to place of residence. The scope of the study is Catalonia as a whole, even though special attention is paid to the city of Barcelona. The paper, from here onwards, is divided into the following sections: Firstly, a brief outline will be given as to the issue of residential and school segregation in Catalonia; after this, the hypotheses and methodology followed are detailed; in the third section, emphasis will be placed on the analysis of the impact of residential and school segregation along educational and training trajectories for Catalan youths; and finally, schooling demand and enrolment in Barcelona's neighbourhoods will be studied as an example of the mechanisms of school segregation. The work will conclude with some overall findings.

\section{Residential Segregation and School Segregation in Catalonia}

The economic recession in Spain, as a result of the real estate bubble and the austerity policies, have brought an increase in poverty, social exclusion, and inequality. Different studies have proven that, since 2008, the recession's impact on the socio-spatial configuration of Spanish cities is extremely relevant $[17,18]$. Similarly noteworthy has been its repercussion in the Barcelona metropolitan area, along with the rest of Catalonia [18,19]. Recent studies have shown that the increase in inequalities has led to an increase in urban residential segregation [20], which has been exacerbated over the period 2001-2012. Thus, in Catalonia, throughout the years indicated, the number of census tracts with extreme segregation (vulnerable or well-off) has shifted from $7.7 \%$ to $19.7 \%$ of the total. In demographic terms, the people who live in census tracts with extreme segregation have gone from $6.8 \%$ to $17.1 \%$ of 
the population. Specifically, in 2012, Catalonia had, on the one hand, 676,459 of its inhabitants living in vulnerable neighbourhoods, whereas 620,259 resided in comfortable neighbourhoods. The relationship of this dynamic with living conditions of the population has been studied by, amongst others, Nel-lo (2016) [21].

In turn, over recent years, several studies have analysed the shortfalls in equity in the Catalan educational system, warning of the growing threat of school segregation [10,22-27]. This process has led to increasing differentiation in the social composition of the schools, with a higher concentration of socially homogenous groups (both students from well-off families and also those in the vulnerable ones). Recent publications of the Jaume Bofill Foundation, specialised in studies about education and its social context in Catalonia, sustain the idea that school segregation is a reality and an unsolved issue in Catalonia [28].

The contextual causes to which the aforesaid studies attribute this situation in Catalonia are widespread: The increase in social inequalities and the deepening residential segregation; the arrival of immigrant students and the outflow of other families; the stigmatisation of certain schools as a result of their social outlook; the worsening of living conditions associated with the economic downturn; along with austerity measures and current educational policies [29], amongst others. It must be mentioned; however, that these contingent causes act in the context of a quasi-market-based educational system, defined by a certain freedom of choice, in a similar manner to the one that leads to residential segregation. That means that the families with the greatest levels of social, cultural, and economic capital are endowed with increased possibilities to choose the school and the type of educational project they want for their children. Within this framework, boosted furthermore through mechanisms and regulations imposed by the schools (such as quotas, fees, or access criteria) and the unequal ability to meet transportation costs, the real power of choice for vulnerable families becomes restricted. As a consequence of the foregoing, certain schools feature a much greater concentration of pupils with greater educational needs. Not surprisingly these are the schools often equipped with fewer teaching staff, materials, and installations. As can be seen, once again, there is a clear parallelism between this phenomenon and that of residential segregation.

School segregation is in line with the stigmatisation of certain neighbourhoods and schools, with this conditioning demand, as it will be seen in the second part of our study. This is a phenomenon that is by no means exclusive to Barcelona or Catalonia, moreover it has been studied and observed by different authors in a number of cities $[22,26,30]$.

The negative impacts of segregation on the school performance of the most vulnerable groups, on the system as a whole, and on social cohesion in our region have been widely contrasted [10,21,25]. Many authors state that school segregation reduces educational opportunities for the most vulnerable population though the so-called "peer effect". Published work often states that students coming from socially vulnerable families obtain worse grades if they are enrolled in socially homogenous schools than if they attend schools with a greater social mix. Even though there is no common agreement, some authors find that this cultural and social mix does not bring, with it, negative effects on the children from higher income families, meaning; therefore, that the effect is asymmetric $[22,25,28]$. In a report issued by Síndic de Greuges de Catalunya [26], the spiral of reproduction of school segregation has been denounced; enrolment and schooling conditions affect the social structure of the schools and these, in turn, influences future enrolment strategies. According to certain authors, this reality becomes a determining factor to call into question equity, educational quality, and social cohesion in the Catalan educational system [10], thereby compromising its role in the equal distribution of opportunities amongst the population [28].

\section{Hypothesis, Materials, and Methods}

The starting point of this paper is the hypothesis that residential and school segregation does not just reflect social inequalities but; moreover, they reproduce and perpetuate them. Specifically, school segregation compromises both the educational system's capacity with regard to ensuring 
equality of opportunities, as well as its role in reducing social inequality. Thus, residential and educational segregation are deemed to be closely interlinked and mutually feed off each other. School segregation largely explains unequal educational paths amongst different social groups. Furthermore, the dynamics of school choice may be a mechanism that heightens segregation at schools, due to the unequal capacity of choice by families in a system where schools compete under unfair conditions.

These hypotheses will be debated through two approaches: On the one hand, the consequences of residential segregation in education; and on the other, the processes of segregation and stigmatisation in certain areas and their schools. Three main sources of data were used: The map of urban segregation in Catalonia; the Enquesta de Joventut de Catalunya (Catalan Youth Survey) 2017; and school enrolment data from Barcelona districts.

As base information on residential segregation, data on urban segregation in Catalonia at a census tract scale from the research Barris $i$ Crisi was taken as a starting point [20]. In that study, a classification of the census tracts in Catalonia was established according to the values of four variables related to income: Percentage of foreign residents, percentage of unemployment, average built-up surface area of the residential property, and its cadastral value. The results of the research established three categories which, in 2012's values, could be specified in the following magnitudes for Catalonia: Inferior extreme segregation (vulnerable neighbourhoods), with 484 census tracts and 676,459 people; extreme superior urban segregation (well-off neighbourhoods), with 586 census tracts and 620,259 people; and areas without extreme segregation (intermediate districts), with 4359 census tracts and $6,386,428$ residents [20].

The second source of information used was the 2017 Catalan Youth Survey, in the analysis of which the variable of residential segregation explained in the foregoing paragraph was included [31]. For this contribution, the data referring to educational paths and levels in the Catalan population aged between 15 and 34 was used.

Finally, a set of statistical information on enrolments in the second cycle of pre-school (P3-P5) and primary education (first to sixth grade) was gathered at a neighbourhood and district level in Barcelona. Specifically, the following data was considered: Population enrolled in pre-school and primary education per neighbourhood, as of 1 January 2017 [32]; location of 364 pre-school and primary schools in Barcelona [33]; enrolments and vacancies in Barcelona's schools for the 2017-2018 academic year [34]; school's characteristics in terms of ownership and complexity [33]; and school performance by districts in the percentage of failure in basic competences-common grades that all students take every two years-by the sixth grade of primary school in 2014 [34].

This data was georeferenced with the aim of carrying out a spatial analysis using geographical information systems (GIS). These tools enabled the mapping and cross-referencing of data and variables, exploring their distribution through neighbourhoods in Barcelona.

\section{Analysis and Results: Segregation and Educational Paths}

As has been indicated, the analysis of the data embraced three aspects: Firstly, the existing relationship between residential segregation and educational paths in the Catalan youth population; secondly, a detailed study of Barcelona in order to study inequality in terms of demands for enrolment in the city's neighbourhoods, and lastly, an analysis of data relating to school performance broken down by districts and related to income.

\subsection{Residential Segregation and Educational Paths in Catalonia}

The analysis of the relationship between residential segregation and the educational paths of the population is a key point of the debate on the neighbourhood effect, in terms of standards of living for the population. When analysing spatial inequalities amongst the youth population the approach taken in this paper paid special attention to urban segregation. This perspective holds particular 
interest amongst this group because in early ages socialisation mostly takes place in the immediate surroundings and in the neighbourhood of residence.

The results of the analysis on a wide-ranging sample of the Catalan population, aged between 15 and 34, has led us to conclude that, currently, the differences and inequalities in the habits and living conditions of the youth population in Catalonia can be better explained by residential segregation than by other spatial features [31]. This means that educational paths, professional activity, participation, etc. amongst the youth population depended more on socio-spatial conditions of the neighbourhood in which they live in than other more traditional classifications, such as the geographical area, the size of the municipality, or the intensity of urban development.

The variables referring to the formal educational system clearly confirmed this point. In 2017, $42.5 \%$ of the Catalan population aged between 15 and 34 were registered as students. This percentage varied in the diverse age groups, being higher with the younger members and lower with the older ones, as they were already entering the labour market. Along general lines, the most prolonged training paths over time corresponded to the highest levels of formal education, such as higher education and even postgraduate studies. Now, it is significant to note that, in all ages, the percentage of the population currently undertaking studies was lower in vulnerable areas than in well-off ones. The difference could be as much as 10 percentage points for the group aged between 25 and 29 years. People in this age range in vulnerable neighbourhoods displayed a lower rate of school enrolment $(16.6 \%)$ than in any other spatial category of analysis. This was a clear sign of the shorter educational paths of the population in these neighbourhoods.

The briefest educational trajectories also coincided with the lower levels of formation. In the vulnerable neighbourhoods, the percentage of the youth population that had not completed compulsory education stood at $16.6 \%$ (amongst those who declare that they had finished studying), almost twice that of the non-vulnerable neighbourhoods ( $8.8 \%)$, and significantly above the Catalan average $(9.9 \%)$.

In this sense, whilst $91.2 \%$ of the youth population in non-vulnerable areas successfully completed compulsory education, in vulnerable areas this was the case for only $83.4 \%$. As Figure 1 shows, the difference grew at the higher levels of education. In the most vulnerable neighbourhoods, only $45.3 \%$ of the young population had completed post-compulsory secondary education, compared to $65.4 \%$ in the rest of the areas.

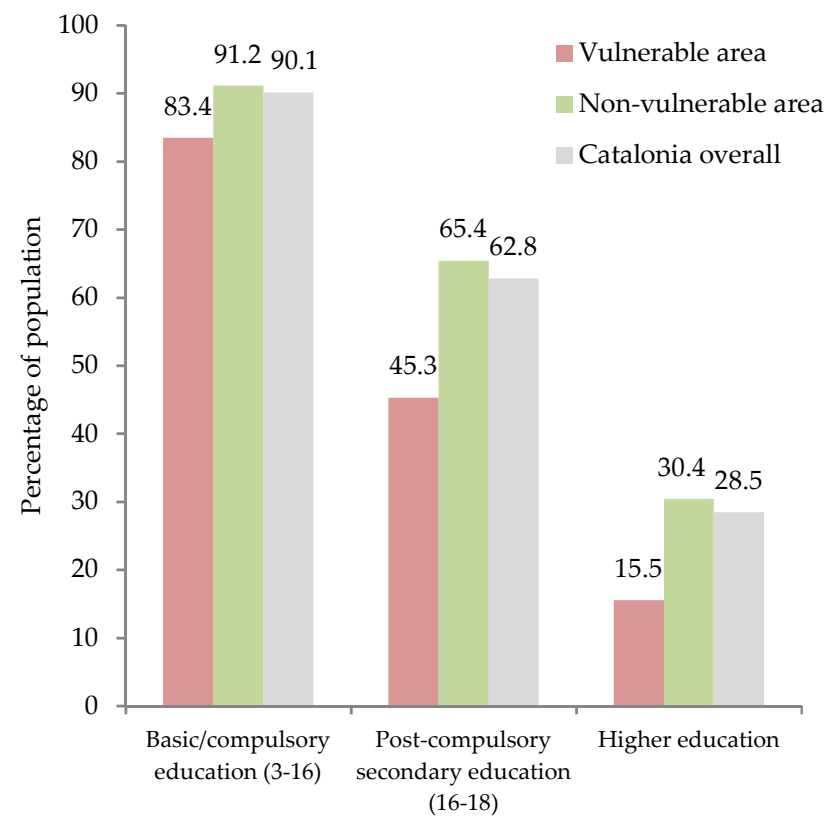

Figure 1. Rates for different educational levels. Population aged 15-34 years who had completed their educational path. Catalan Youth Survey 2017. 
With regard to higher studies, merely $15.5 \%$ of young people in inferior segregation neighbourhoods held university degrees, compared to $30.4 \%$ in the rest. This behaviour was related to future expectations, the peers with whom the youth socialises, and also the economic possibilities of people in vulnerable areas; $23.8 \%$ of young people in vulnerable areas stated that they had to leave their studies in the last two years, or that they have not been able to enrol in those studies they would wish to owing to financial difficulties.

The results of the variables analysed showed that the neighbourhood's level of segregation influenced youths' educational paths more than any other territorial variable.

\subsection{Choosing Schools in Barcelona}

Another dimension of the relationship between segregation and educational training can be perceived through the study of spatially differentiated school enrolment patterns and strategies. This could be studied specifically through school enrolment data from the city of Barcelona. It is worthwhile noting that the city had, in its 73 neighbourhoods (Figure 2), a total of 364 schools offering the second cycle of pre-school (ages three to five) and primary (ages six to 12), of which 172 were state-run and 192 were private or part-financed schools. In total, these schools had approximately 130,300 places. With regard to the population, Barcelona's city census in 2017 recorded 124,504 children in ages of pre-school and primary school. On the other hand, it was found that a total of 127,153 pupils were enrolled in schools in the city, which gives a positive balance of 2649 enrolments and implies that some children travelled into schools from outside the city.

As has been mentioned beforehand, literature reveals the trend of families to enrol their offspring in neighbourhoods with greater economic power and a more positive social image than their own. In this way, well-off neighbourhoods tend to welcome students from other parts of the city and, conversely, vulnerable neighbourhoods end up relinquishing part of their school population to other neighbourhoods. A way to verify the existence of such a dynamic is through the differential values of students enrolled and the population with school age in each neighbourhood. With this method, the value obtained indicates whether the neighbourhood has more students enrolled in its schools than its corresponding school age population (positive balance), or, oppositely, fewer students enrolled in its schools than its school age population (negative balance). The former receives students from other parts of the city and, in the opposite sense, the latter send school age students outside of the neighbourhood. It is worthwhile mentioning that the data available allowed for the obtainment of the general balance for each neighbourhood, but not the determination of which neighbourhood students come from or to where they travel.

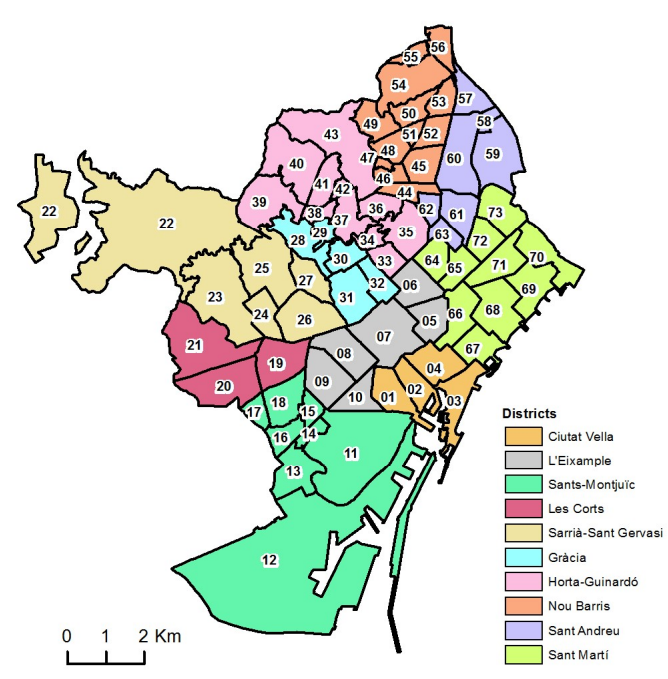

Figure 2. Districts and neighbourhoods of Barcelona.

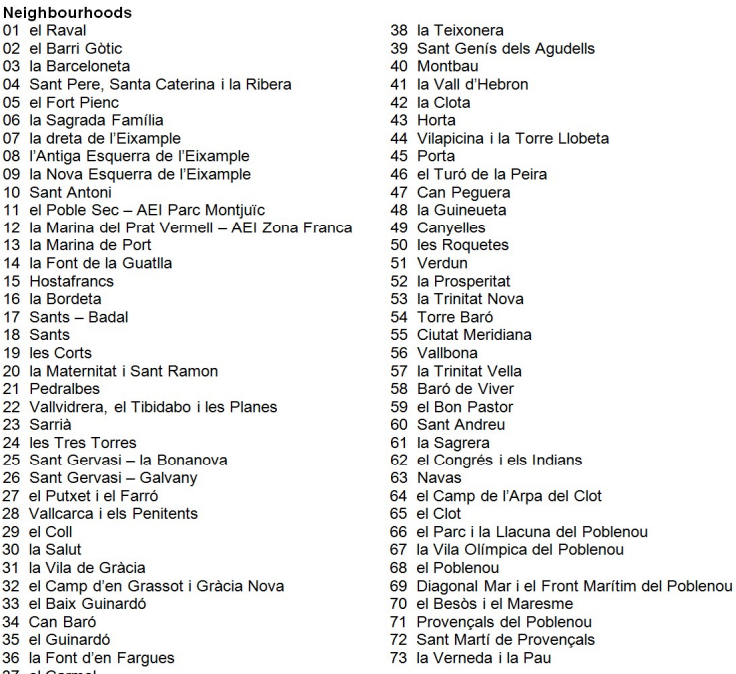


As can be seen in the map given in Figure 3, there were notable differences amongst neighbourhoods with regard to the balance between enrolments and the school age population. These have been represented on the map in diverse tones of red, showing the neighbourhoods with less enrolments than school age population (low retention) and, in green, those which, in the opposite sense, had more students enrolled in their schools than residents with school age. On the other hand, the number represented on the map for each neighbourhood corresponds to the balance between enrolments and the school age population in absolute values.

Amongst the districts with the highest positive balance, we found, running from East to West, the neighbourhoods of Font d'en Fargues, Vall d'Hebrón, Sant Gervasi-Bonanova, Sarrià, and Pedralbes, which exceed $100 \%$ (dark green on the map), meaning that in these areas the number of enrolments doubled, and at times tripled, their school age population. Paying attention to absolute values, the neighbourhood of Sarrià was where the difference between its enrolled students and its school age population was greatest, with a positive balance of 7089 enrolled students. In general terms, the neighbourhoods with the greatest powers of attraction coincided with those that had the highest average incomes in the city (Sant Gervasi-Bonanova, Sarrià, and Pedralbes), yet also with those in a relatively comfortable situation with respect to those in their surroundings, as would be the case of Sant Andreu, la Prosperitat, and la Dreta del Eixample.

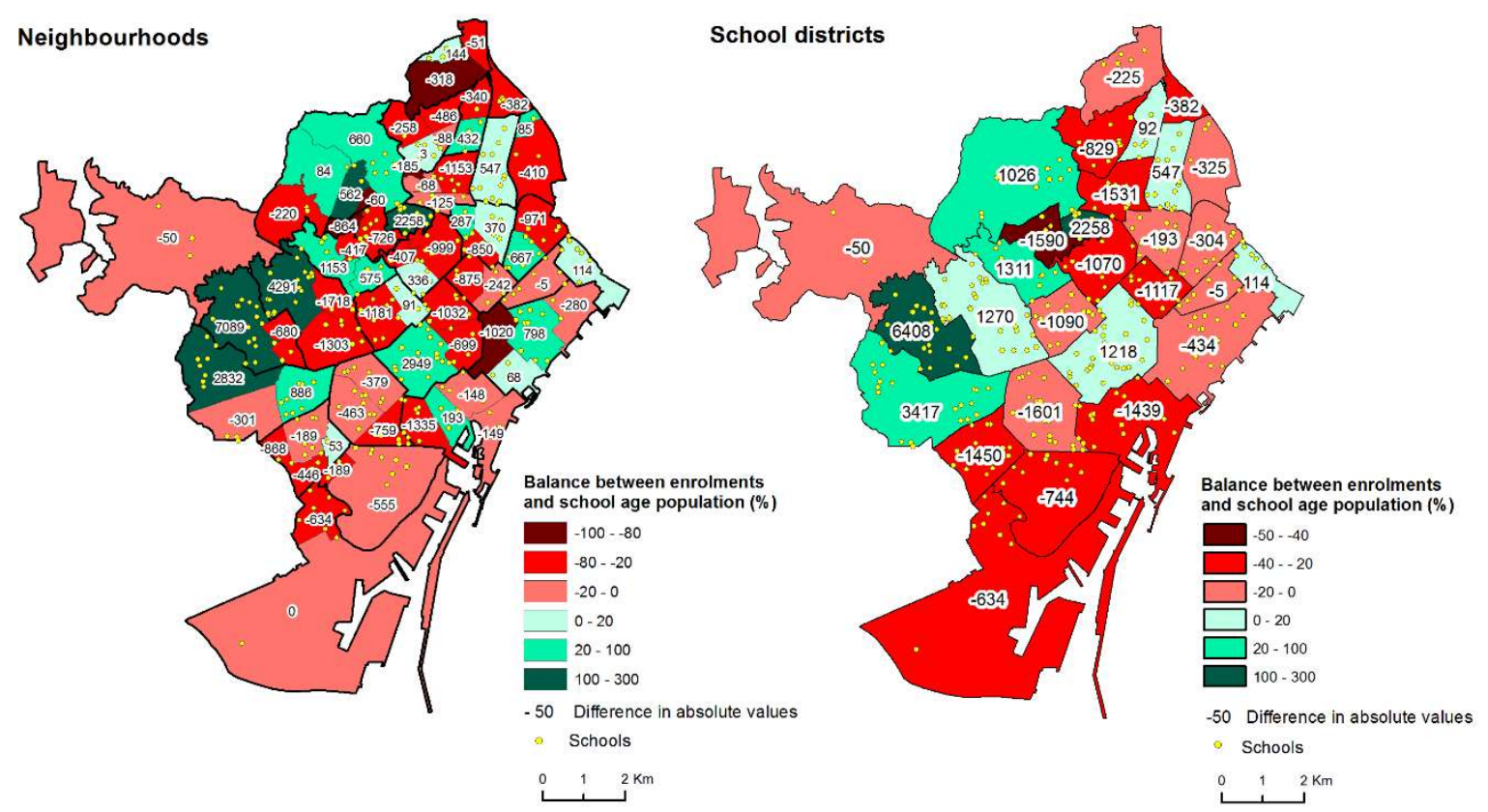

Figure 3. Attraction and discharge of the school age population by neighbourhoods and school districts in Barcelona, 2017.

At the opposite end of the scale (maroon on the map), we found Torre Baró, la Clota, la Teixonera, and el Parc i la Llacuna del Poblenou, whose school age population tended to be enrolled outside the neighbourhood where they live. This trend could be explained as a result of the paucity of school places in these neighbourhoods. However, it was also observed that an important number of neighbourhoods that boasted a well-served educational network sent students to other areas, namely la Trinitat Nova, Bon Pastor, el Raval, Sant Antoni, La Bordeta, etc. These were, largely, neighbourhoods with lower average incomes than other neighbourhoods in their surroundings.

This behaviour also explains the presence of certain neighbourhoods with relatively low-income levels, which, conversely, had more enrolments than the school age population. This was the case, for example, of Besòs-Maresme, Baró de Viver, Ciutat Meridiana, and la Prosperitat. As has been mentioned beforehand, data about the neighbourhood where each student lives was not available, but it seemed that Baró de Viver and Besós-Maresme attracted, respectively, students living in Bon Pastor 
and in Sant Adrià de Besòs (specifically from la Mina neighbourhood). Ciutat Meridiana probably attracted the school age population from Torre Baró and Can Cuiàs, which belongs to the adjacent city of Montcada i Reixac. Finally, la Prosperitat, the centre of Sant Andreu, and la Font d'en Fargues were relatively wealthier neighbourhoods than those surrounding them. Thus, it could be observed that, in general terms, neighbourhoods with the highest income levels and best reputations were those that had more enrolments than they should in relation to their number of school age residents. Certain exceptions to this rationale have been observed, such as, for example, the neighbourhoods of Tres Torres, Sant Gervasi-Galvany, and el Putxet i el Farró, which were comfortable neighbourhoods though they displayed a low level of self-containment in terms of school age population. According to the proximity and the school district map (second map in Figure 3), it seemed that their students travelled to bordering neighbourhoods that also had a high income.

In the second map in Figure 3, the difference between the number of enrolments and the school age population of the 29 school districts is represented. School districts are integrated by sets of proximity centres. Residence in one of these areas constitutes one of the prioritisation criteria to obtain a place in the school of choice, whether this is a state school or a part-financed school. Data displayed wholly confirmed the main features unearthed through the analysis undertaken in relation to the neighbourhoods. The fact that, despite the existence of school districts-intended, in theory, to ensure school enrolment under terms of equality for the school age population near its place of residence-there was an outflow of the population, shows a shortfall in the system's effectiveness.

With the aim of complementing this analysis, vacancies in each school were studied for each neighbourhood and school district. As can been seen in the map in Figure 4, the number of school vacancies was not homogenous in all Barcelona. On the one hand, there were 15 neighbourhoods that had a deficit in absolute terms of school places (shades of green), to which those with zero vacancies must be added. These were neighbourhoods with a high demand in terms of school enrolment, with more demand than availability. Worthy of special mention in terms of schooling demand was Sant Andreu, which as has already been mentioned, was one of the most well-off neighbourhoods in the northeast area of the city.

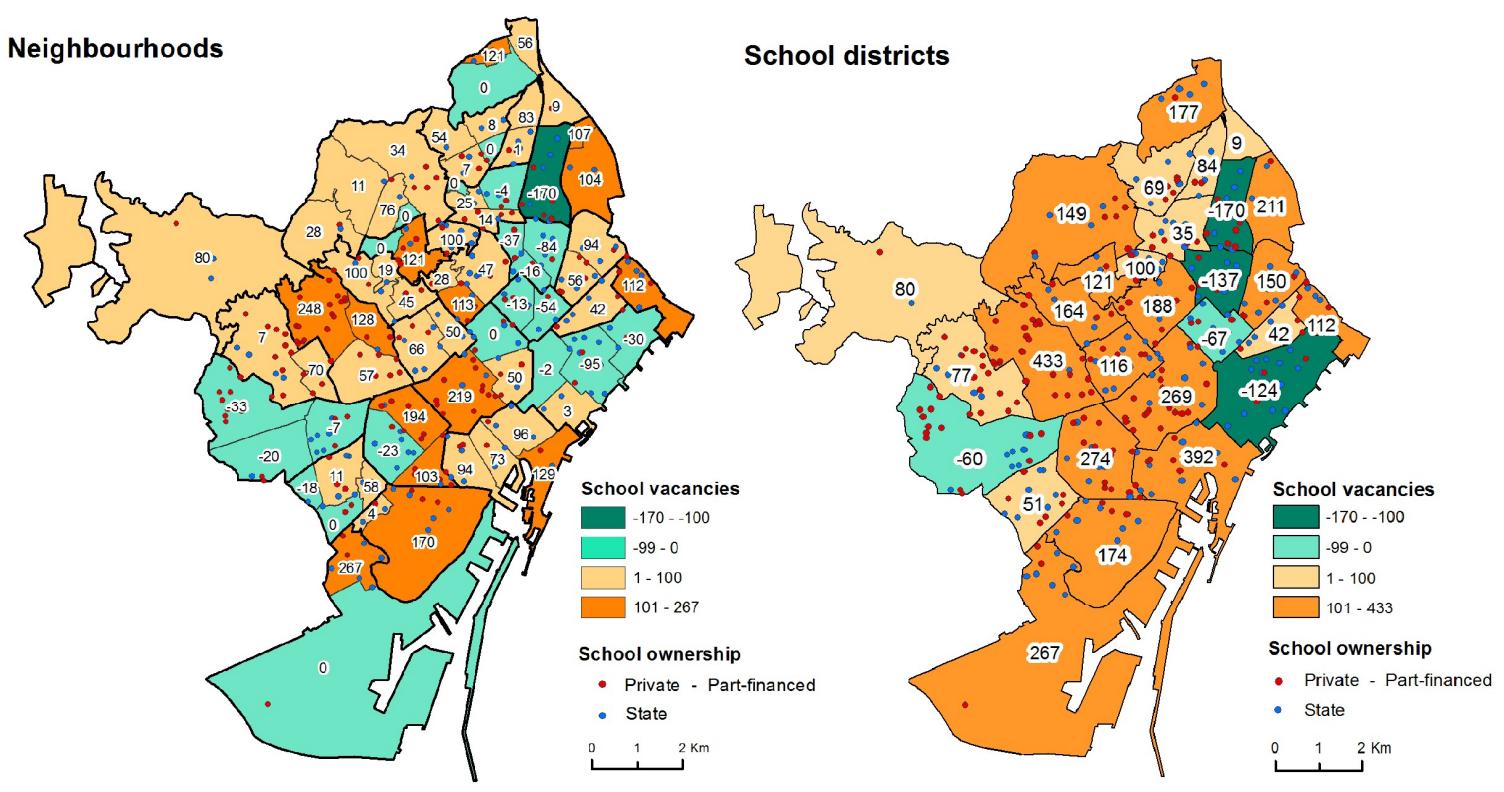

Figure 4. School vacancies (P3-P6) by neighbourhoods and school districts in Barcelona, in the 2017-2018 academic year.

On the other hand, as can be observed in the same map in orange tones, there were 50 neighbourhoods in Barcelona that had a significant number of school vacancies. If we compared this map with the one on income by neighbourhood (2016), it could be seen that the areas that had 
school vacancies were, firstly, those which had lower income levels, namely Bon Pastor, Baró de Viver, Ciutat Meridiana, and la Barceloneta. Alongside these, we could also find neighbourhoods with higher income levels, such as Dreta de l'Eixample or all of those that comprise the district of Sarrià-San Gervasi. This situation had a dual explanation: In the case of the vulnerable neighbourhoods, this was due to weak demand levels and the failure to retain own school age population in the neighbourhood; however, in the well-off neighbourhoods, this was explained by the predominance of private or part-financed schools. These schools, unlike those which were wholly state run, offered many places without overly careful adjustment to demand.

By focusing on neighbourhoods with school vacancies and with low income, worthy of further attention were the cases of Vallbona, Trinitat Nova, and les Roquetes, which had a highly elevated number of unfilled places despite only having one school, which was, furthermore, state run. The figures of the 54 unfilled school spaces in Roquetes, 56 in Vallbona, and 83 in Trinitat Nova indicated clearly that families in these neighbourhoods, despite having vacant places nearby, preferred to enrol their children in pre-school and primary centres in neighbouring areas.

If we observe the second map in Figure 4, with the school vacancies by school districts, it can be seen how Sant Andreu, Navas-la Sagrera-el Congés i els Indians, and el Parc i la Llacuna-la Vila Olímpica del Poblenou-Diagonal Mar i el Front Marítim del Poblenou-Poblenou, were areas that had more demand than the number of places on offer. In the opposite sense, two axes that show school vacancies were clearly detected: Running from North to South, from Horta-Guinardó to Sants-Montjuïc; and the section in the Besós River area. This could also be explained by the duality already mentioned; some of the areas having a surplus of vacancies were neighbourhoods with a low income (such as Ciudad Meridiana- Torre Baró-Vallbona), whilst others comprised well-off neighbourhoods that displayed a high number of unfilled school places due to the predominance of privately-owned or part-financed schools (as is the case of Putxet i Farró-San Gervasi-Bonanova-Sant Gervasi-Galvany).

\subsection{Inequalities in School Performance}

The final part of this paper analyses the relationship between the socio-economic variables, the complexity of the schools' situation, and the academic results of the students. The available data on school performance refers to the percentage of students in the sixth grade of primary school that did not achieve the basic competence in the 2013-2014 academic year [34]. In this case, no data detailed by neighbourhoods was available and, for this reason, work was undertaken with the 10 districts of Barcelona.

As can be seen in Figure 5, the districts with a higher percentage of students that failed basic competences at sixth grade were those of Ciutat Vella and Nou Barris, with the percentage standing at around $20 \%$. Following these, with fail rates at around 12\%, we found Sant Martí, Horta-Guinardó, and Sant Andreu. The district of Gracia showed a 10\% fail rate and Eixample an $8.5 \%$ fail rate. Finally, the districts showing the best results were Les Corts and Sarrià-Sant Gervasi, with merely $5 \%$ of the students failing these tests. It is worthwhile highlighting that the differences were highly remarkable, reaching up to 15 percentage points between districts.

Complementary information refers to school complexity. Maximum complexity schools were defined by the Departamanet d'Ensenyament (Teaching Department) based on the following context variables: Low parental level of instruction, parental employment on low professional qualification posts, significant number of parents of students receiving guaranteed minimum income, high percentage of parents unemployed, high percentage of students with specific educational needs, and high percentage of immigrants. The results clearly showed a direct relationship between the number of schools defined with the category of maximum complexity and the percentage of sixth grade primary students that did not achieve the basic competences, with an adjustment rate of $R^{2}=0.7464$. In this sense, the districts with the most schools deemed to be in complex situations (Ciutat Vella, Nou Barris, Sants-Montjuïc, and Sant Martí) were the ones with the most deficient results on the basic 
competences. These results may be the expression of the spiral of reproduction of school segregation, specifically of the conditions of vulnerability experienced by some areas and schools.

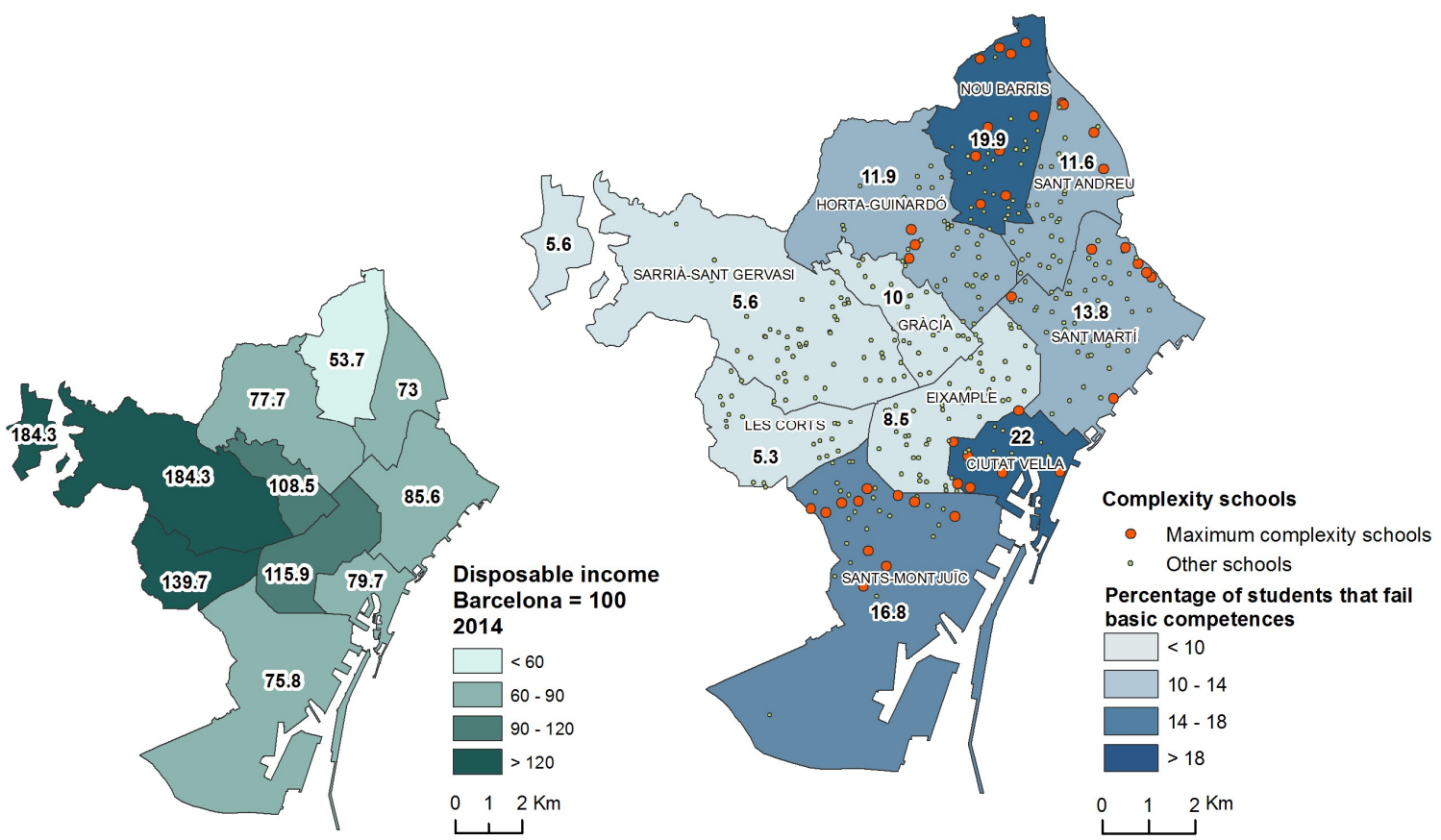

Figure 5. Disposable income per capita (Barcelona $=100)$ and percentage of students that failed basic competences tests (\%) by districts in Barcelona, 2014.

The relationship between academic performances and the average disposable income was even more revealing. As can be seen from Table 1 and Figures 5 and 6, the relationship was of an inverse nature: the lowest percentages of students failing basic competences corresponded to the higher income districts (that is, the districts of Sarrià-Sant Gervasi and Les Corts, as well as those of Eixample and Gràcia). In the opposite sense, where the average income was lower, the percentage of students that failed basic competences was higher (as can be seen in Nou Barris, Ciutat Vella, and Sants-Montjuïc). Literature dealing with the "neighbourhood effect" as a generator and perpetuator of social inequalities would undoubtedly find food for thought in this data.

Table 1. Disposable income, percentage of students that failed in basic competences tests (\%), and the number of maximum complexity schools in Barcelona by district.

\begin{tabular}{lccc}
\hline \multicolumn{1}{c}{ District } & $\begin{array}{c}\text { Disposable Income per Capita } \\
\text { 2014 (Barcelona = 100) }\end{array}$ & $\begin{array}{c}\text { Failed on Basic } \\
\text { Competences in 6th } \\
\text { Grade, 2014 (\%) }\end{array}$ & $\begin{array}{c}\text { No. Maximum } \\
\text { Complexity Schools }\end{array}$ \\
\hline 1. Ciutat Vella & 79.7 & 22 & 7 \\
2. Eixample & 115.9 & 8.5 & 0 \\
3. Sants-Montjuïc & 75.8 & 16.8 & 11 \\
4. Les Corts & 139.7 & 5.3 & 0 \\
5. Sarrià-St Gervasi & 184.3 & 5.6 & 0 \\
6. Gràcia & 108.5 & 10 & 0 \\
7. Horta-Guinardó & 77.7 & 11.9 & 3 \\
8. Nou Barris & 53.7 & 19.9 & 4 \\
9. Sant Andreu & 73 & 11.6 & 7 \\
10. Sant Martí & 85.6 & 13.8 & 4 \\
\hline
\end{tabular}




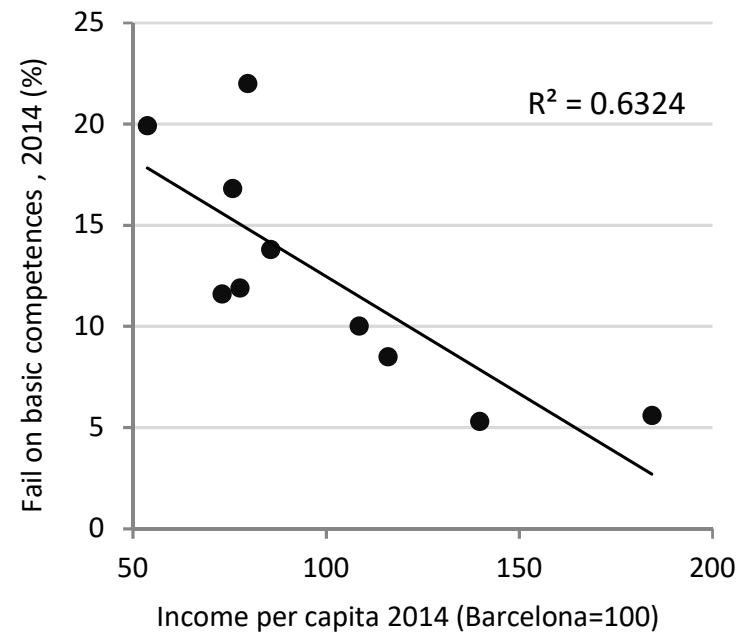

Figure 6. Relationship between disposable income and scholar performance.

\section{Conclusions}

This article has explored the relationship between urban segregation, on the one hand, and the education levels obtained by the population, on the other. Specifically, the spatial distribution of social groups has been studied in relation to two types of variables: (a) Educational levels amongst the Catalan youth population; and (b) the differences in terms of enrolment and educational performance in the neighbourhoods and districts of Barcelona. In this way, this paper examined the relationship between urban segregation and inequality from one of the aspects with, undoubtedly, the most weighting in the (re)production of social inequality-education.

Based on the analysis carried out, it would seem feasible to state that the place of residence, specifically the neighbourhood, and its conditions (amenities, social conditions, accessibility, services) are related to educational trajectories and expectations of the youth population, acting, thus, as a mechanism for the (re)production of social inequality. It has been verified, for example, in 2017, that the proportion of the youth population living in non-vulnerable neighbourhoods obtained double the number of university titles than compared to those living in vulnerable neighbourhoods.

On the other hand, spatial differences in schools' conditions act as enhancer elements for school segregation, due to, above all, the stigmatisation of schools in vulnerable neighbourhoods and the enrolment procedure. It can be highlighted that families who have a greater capacity of choice tend to send their children to schools outside the most vulnerable neighbourhoods. In most of the vulnerable neighbourhoods we find less school enrolments than the current population aged between three and 12 living there, even in the cases when there are state schools with vacancies. This process may act as a spiral of reproduction of school segregation (and as a result, residential segregation), confining students with greatest educational needs in the schools in vulnerable neighbourhoods, a process that bears a relation with the "white flight" phenomena mentioned at the start of the article.

To ensure equal opportunities all schools should have the same educational conditions. This would surely require a greater investment in terms of human, educational, and material resources in the most vulnerable areas, with the aim of meeting the greater needs of the students largely coming from families with socially vulnerable backgrounds, lower incomes, and migrant origins. These actions, aside from guaranteeing the equality of conditions and opportunities, would increase the appeal of schools suffering stigmatisation, and would contribute to stop or revert the spiral that leads to growing segregation. School segregation and residential segregation, thus, appear to be inextricably linked. Any policy addressing these dynamics will have to deal with them together. 
Author Contributions: Data curation, A.G.G. and J.M.A.; formal analysis, J.M.A.; methodology, A.G.G. and J.M.A.; visualization, J.M.A.; writing-original draft, A.G.G. and J.M.A.; writing—review and editing, A.G.G.

Funding: This research has been funded with contributions of the following institutions: Ministerio de Economia, Industria y Competitividad. Programa Retos-Project: Efecto Barrio. Los impactos sociales de las desigualdades territoriales y las politicas urbanas redistributivas en las grandes ciudades Españolas; Agència Catalana de Joventut Projecte: Enquesta de Joventut de Catalunya, 2017. Cooperation agreement with Universitat Autònoma de Barcelona; Ministerio de Educación, Cultura y Deporte-Beca de colaboración.

Conflicts of Interest: The authors declare no conflicts of interest.

\section{References}

1. Nel·lo, O.; López, J. El procés d'urbanització. In Raó de Catalunya. La Societat Catalana al Segle XXI; Giner, S., Homs, O., Eds.; Institut d'Estudis Catalans i Enciclopèdia Catalana: Barcelona, Spain, 2016; pp. 119-148.

2. Indovina, F. La Ciudad de Baja Densidad: Lógicas, Gestión y Contención; Diputació de Barcelona: Barcelona, Spain, 2007.

3. Soja, E.W. Seeking Spatial Justice; Univeristy of Minnesota Press: Minneapolis, MN, USA, 2010.

4. Tammaru, T.; Marcinczak, S.; Van Ham, M.; Musterd, S. Socio-Economic Segregation in European Capital Citites. East Meets West; Routledge: London, UK, 2016.

5. Secchi, B. La Città dei Ricchi e la Città dei Poveri; Laterza: Bari, Italy, 2013.

6. Atkinson, R.; Kintrea, K. Disentangling Area Effects: Evidence from Deprived and Non-deprived Neighbourhoods. Urban Stud. 2001, 38, 2277-2298. [CrossRef]

7. Galster, G.; Anderson, R.; Mustered, S. Who is affected by neighbourhood income mix? Gender, age, family, employment and income differences. Urban Stud. 2010, 47, 2915-2944. [CrossRef]

8. Slatter, T. Your Life Chances Affect Where You Live: A critique of the 'Cottage Industry' of Neighbourhood Effects Research. Int. J. Urban Reg. Res. 2013, 37, 367-387. [CrossRef]

9. Cheshire, P. Segregated Neighbourhoods and Mixed Communities. A Critical Analisys; Joseph Rowntree Foundation: York, UK, 2007.

10. Bonal, X. La política educativa ante el reto de la segregación escolar en Cataluña. Int. Inst. Educ. Plan. 2018, 7-17. Available online: http:/ / unesdoc.unesco.org/images/0026/002614/261471s.pdf (accessed on 4 April 2018).

11. Sikkink, D.; Emerson, M.O. School schoice and racial segregation in US schools: The role of parents' education. Ethnic Racial Stud. 2008, 31, 267-293. [CrossRef]

12. Bagley, C. Black and white unite or flight? The racialised dimension of schooling and parental choice. Br. Educ. Res. J. 1996, 22, 569-580. [CrossRef]

13. Burgess, S.; McConnell, B.; Propper, C.; Wilson, D. The impact of school choice on shorting by ability and socioeconomic factors in English secondary education. In Schools and the Equal Opportunity Problem; Wössmann, L., Peterson, P.E., Eds.; MIT Press: Cambridge, UK, 2007.

14. Cullen, J.B.; Jacob, B.A.; Levitt, S.D. The impact of school choice on studemt outcomes: An analysis of the Chicago public schools. J. Public Econ. 2005, 85, 729-760. [CrossRef]

15. Gewirtz, S.; Ball, S.; Bowe, R. Markets, Choice and Equity in Education; Univerisity Press: Buckingham, UK, 1995.

16. Bonal, X.; Zancajo, A. Educació, pobresa i desigualtats en un context de crisi. Nota d'economia 2016, 103, 91-103.

17. Méndez, R.; Abad, L.D.; Echaves, C. Atlas de la crisis. In Impactos Socioeconómicos y Territorios Vulnerables en España; Tirant lo Blanch: Valencia, Spain, 2014.

18. Nel·lo, O.; Donat, C. Los efectos territoriales de la crisis en la región metropolitana de Barcelona. In Geografía de la Crisis Económica en España; Albertos, J.M., Sánchez, J.L., Eds.; Publicaciones de la Universitat de València: Valencia, Spain, 2014; pp. 565-608.

19. Sarasa, S.; Porcel, S.; Navarro-Varas, L. L'impacte social de la crisi a l'Àrea Metropolitana de Barcelona i a Catalunya. Papers 2013, 56, 10-87.

20. Blanco, I.; Nello, O. Barrios y Crisis. Crisis Económica, Segregación Urbana e Innovación Social en Catalunya; Tirant lo Blanch: Valencia, Spain, 2018. 
21. Nel·lo, O. Desigualdad social y segregación urbana en la región urbana de Barcelona. In Estudios de Geografía Urbana en Tiempos de Crisis. Territorios Inconclusos y Sociedades Rotas en España; Brandis, D., del Río, I., Morales, G., Eds.; Biblioteca Nueva: Madrid, Spain, 2016.

22. Benito, R.; Gonález, I. Processos de segregació escolar a Catalunya. Fundació Jaume Bofill 2007, 59, 11-155. Available online: http:/ / www.fbofill.cat/sites/default/files/464.pdf (accessed on 6 April 2018).

23. Síndic de Greuges. La segregació escolar a Catalunya. Informe Extraordinari. Síndic de Greuges 2008, 5-131. Available online: https://www.sindic.cat/site/files/docs/60_INFORME\%20SEGREGACIO\%20ESCOLAR. pdf (accessed on 6 April 2018).

24. García-Castaño, F.J.; Olmos alcaraz, A. Segregaciones y Construcción de la Diferencia en la Escuela; Trotta: Madrid, Spain, 2012.

25. Martínez, M.; Albaigés, B. L'estat de l'educació a Catalunya. Anuari 2013. Fundació Jaume Bofill 2013, 80, 13-563. Available online: http:/ / www.fbofill.cat/sites/default/files/582.pdf (accessed on 6 April 2018).

26. Síndic de Greuges. La segregación escolar en Cataluña (I): La gestión del proceso de admisión del alumnado. Síndic de Greuges 2016. Available online: http:/ / www.sindic.cat/site/ unitFiles/4155/Informe\% 20segregacion\%20escolar_I_gestionprocesoadmision_castellano_def.pdf (accessed on 7 April 2018).

27. Síndic de Greuges. La segregación escolar en Cataluña (II): Condiciones de escolarización. Síndic de Greuges 2016. Available online: http:/ / www.sindic.cat/site/unitFiles/4227/Informe\%20segregacio\%20escolar_II_ condicions_escolaritzacio_cast_ok.pdf (accessed on 7 April 2018).

28. Alegre, M.A. Polítiques de tria i assignació d'escola: Quins efectes tenen sobre la segregació escolar? Què Funciona en Educació 2017, 1-41. Available online: http: / / www.fbofill.cat/sites / default/ files / Que_funciona_ 07_segregracioescolar_301017.pdf (accessed on 7 April 2018).

29. Bonal, X.; Tarabini-Castellani, A.; Verger, A. La nova política educativa i les desigualtats. Nous Horitzons 2015, 209, 16-21. Available online: http:/ / www.noushoritzons.cat/sites/default/files/la_nova_politica_ educativa_i_les_desigualtats.pdf (accessed on 7 April 2018).

30. Alegre, M.A.; Benito, R.; Chela, X.; Gonález, S. Les famílies davant l'elecció escolar. Dilemes i desigualtats en la tria de centres a la ciutat de Barcelona. Fundació Jaume Bofill 2010, 72, 11-304. Available online: http:/ / www.fbofill.cat/sites/default/files/528.pdf (accessed on 7 April 2018).

31. Nel·lo, O.; Gomà, A. Territori. Diversitat espacial en els hàbits i condicions de vida juvenils: El paper clau de la segregació residencial. In Enquesta de Joventut de Catalunya; Serracant, P., Ed.; Generalitat de Catalunya: Barcelona, Spain, 2018.

32. Departament d'Estadística, Ajuntament de Barcelona. Available online: http://www.bcn.cat/estadistica/ catala/index.htm (accessed on 5 December 2017).

33. Departament d'Ensenyament, Generalitat de Catalunya. Available online: http://ensenyament.gencat.cat/ $\mathrm{ca} /$ inici (accessed on 31 January 2018).

34. Consorci d'Educació de Barcelona, CEB. Available online: http://edubcn.cat/ca/ (accessed on 11 December 2017).

(C) 2018 by the authors. Licensee MDPI, Basel, Switzerland. This article is an open access article distributed under the terms and conditions of the Creative Commons Attribution (CC BY) license (http:/ / creativecommons.org/licenses/by/4.0/). 